\title{
COMMUNITY AND ARCHITECTURE: CONTRIBUTION RETROSPECT IN KARACHI DURING THE BRITISH RAJ CASE OF SADDAR BAZAAR
}

\author{
Hira Ovais*
}

\begin{abstract}
Communities play a vital role in the development of any society, both in terms of political and commercial ambiance and culture and social character, which contributes in the city formation. Karachi is an excellent example of it. Over the years the city has evolved from wilderness to being one of the most populous cities of the world. It houses many imported traditions, which have mixed with local values over the years.
\end{abstract}

Karachi, in 1900 s was dominated by many ethnic communities, which resulted in the rise of a class system, which in turn lead to the emergence of communal enclaves to create a sense of communal values. Until independence of the sub-continent in 1947, these communities worked together and flourished in Karachi.

Saddar bazaar, the city centre of Karachi was mainly occupied by these communities. Saddar was laid as a camp by the British in the late nineteenth century and was later used not only as a marketplace, but also consisted supporting functions like storage facilities, religious places, schools, coffee houses, cinemas, bars, billiard rooms, restaurants and residential areas. The merchants who came from India started their commercial activities here. During the Colonial rule, Saddar flourished not only in terms of trade and commerce, but also in terms of architecture.

By the $19^{\text {th }}$ century the British had already established a design language for the architecture of the public buildings of the sub-continent. But after the involvement of the local communities, this language was transformed and either hybrid forms were created (i.e. blending of European features with balconies and chajjas (overhangs) of different proportions) or purely local architectural forms based on the requirement of the locals were constructed. The transformation of European architectural language and its ornamentation into local buildings were observed in many structures. Some of them were built by British architects and engineers and others by the local firms under the British influence.

This paper documents and analyses two such hybrid design buildings, which reflect the lifestyles of the communities through the built form characteristics, details and formal and spatial characteristics.

Keywords: Communities, Businessmen, Architects, Engineers, Ornamentation, Transformation

\section{INTRODUCTION}

Cultural values of any city symbolize homogeneity and uniqueness in its character. It helps us to understand physical, psychological and social importance of a historic area. In Karachi, many of the Colonial buildings are still intact, and reflect the power of the once ruling British class. For Karachi, it was not only rule and power of the British, but also an intention to bring cultural transformation in the people, bending of the natives to accept the British dominance and the struggle with their identity. The most prominent development of the British, after the placement of their camps was the grid iron formulation ${ }^{i}$, which was observed in Saddar bazaar.

Buildings in Saddar bazaar not only contributed in creating socially responsive environment, but also had a historical importance, as they were constructed usually by the British who had become prosperous enough to mark their achievements in the form of these beautiful buildings for the future generations to witness. Roads like Elphinstone, Victoria, Preedy and Clarke within Saddar, have historical significance as they mark the chronological development of the city.

* $\quad$ Architect Hira Ovais (B.Arch, NED University, M.Arch, UET-Lahore), currently in private practice. 
The communal boom ${ }^{\mathrm{ii}}$ was witnessed during the British rule when some of the Goans and Parsis came to Karachi and started investing in businesses. Their businesses flourished and with that came the need to develop an architectural vocabulary reflecting their ethnicity, which was a hybrid of the Colonial and local forms. This period saw a number of philanthropists involved in the construction of many public buildings for providing necessary facilities to the general public. The participation of other communities such as Bohris, Khojas, Jews, Muslims and Hindus, in the construction activity, was also seen during this peirod. These communities either hired builders for their buildings, or professional architects.

\section{Karachi - Origins and British Annexation}

Karachi, the metropolitan city of Pakistan, is not an ancient town nor does it have any historical monuments or archeological remains. It was a small fisherman's village with various names pronounced as Kolachi-jo-kun, Krokala,

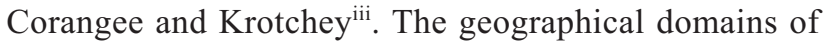
Karachi attracted the British after installing their first factory in Thatta and it was said that "Karachi was the first place to be added to the British possession at the commencement of the reign of her Gracious Majesty Queen Victoria"1. So the British warships and seaborne troops were sent for Karachi from Bombay ${ }^{\text {iv }}$.

Before the arrival of the British, Karachi was a part of the chieftains who had control over the Hub Malir region and the Makran coast. In the seventeenth century, the region was in the control of the Kalmati Maliks, who had dominated the area perhaps since the thirteenth century. The rise of Kalhora rulers of Sindh from Larkana district and the unification of Sindh, under their rule, saw the control of Karachi passing to them in 1795. Until this time, the

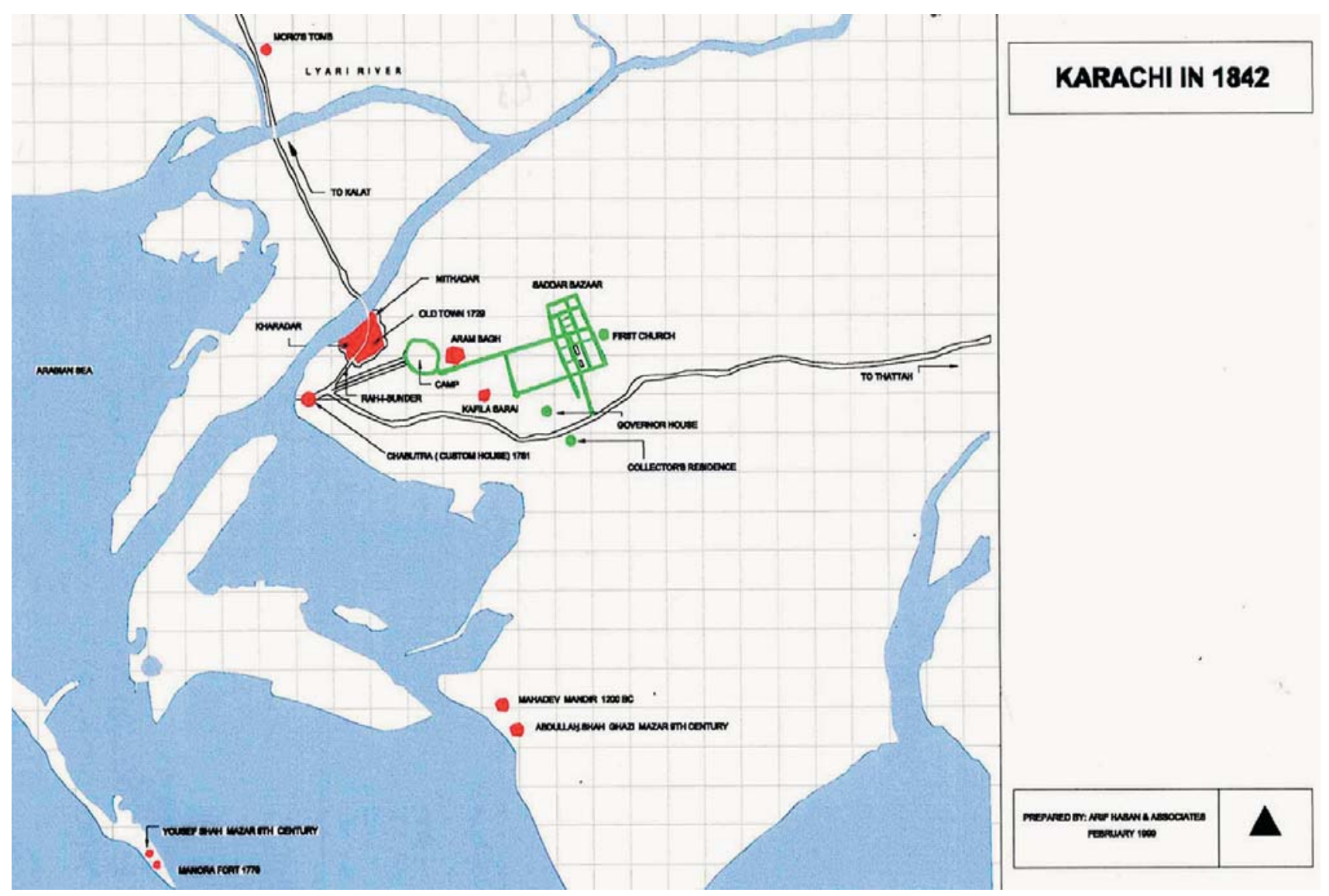

Figure 1: Karachi Map: 1842

1 (Rustomji, Karachi: 1839-1947: A Short History of the Foundation and Growth of Karachi, 2007) 
settlement of Karachi was based primarily on the Lyari River only. Later on it was inhabited by Hindu and Muslim merchants, after the area saw a boom in trading activities. This area, eventually to be referred to as "Old Town" was characterized by narrow winding streets, seldom provision of open spaces and residences of Hindus and Muslims primarily (see Figure 1). The co-existence of these two religious sects also saw the presence of both temples and mosques, all lined along the same streets, with other religious buildings including dharamshalas, shrines, imam bargas. As far as the markets was concerned, the area was primarily dedicated to wholesale activity, with markets such as Dhan Mandi and Khajji Market, that conducted dealings related to the Port of Karachi².

Charles Napier was appointed as the first Governor for the province of Sind in 1842. He planned several development schemes for Karachi. Till this time, EIC (East India Company) governed the city in an informal manner. The initial works on Karachi were mostly based on urban interventions (see Figure 2), such as construction of docks at the harbor and timber pier at Kiamari. The only architectural formations at this time were seen in the form of Napier Barracks for the British military. In 1847, before Napier left Sindh, he built Napier Barracks for the European Army. It was built as an exquisite engineering expression, and still stands in its grandeur on the eastern side of the city. The British established their camp, in what is known today as 'Rambagh Quarters', away from the native town or 'Black Town'v . Later on, they shifted their camp to Saddar Bazaar, a cantonment area, for administrative purposes, to show their power and domination. This area was named as the 'White Town'- and was also an elite hub for the wives of the British military officers. Other developments in Karachi included the first rail service,

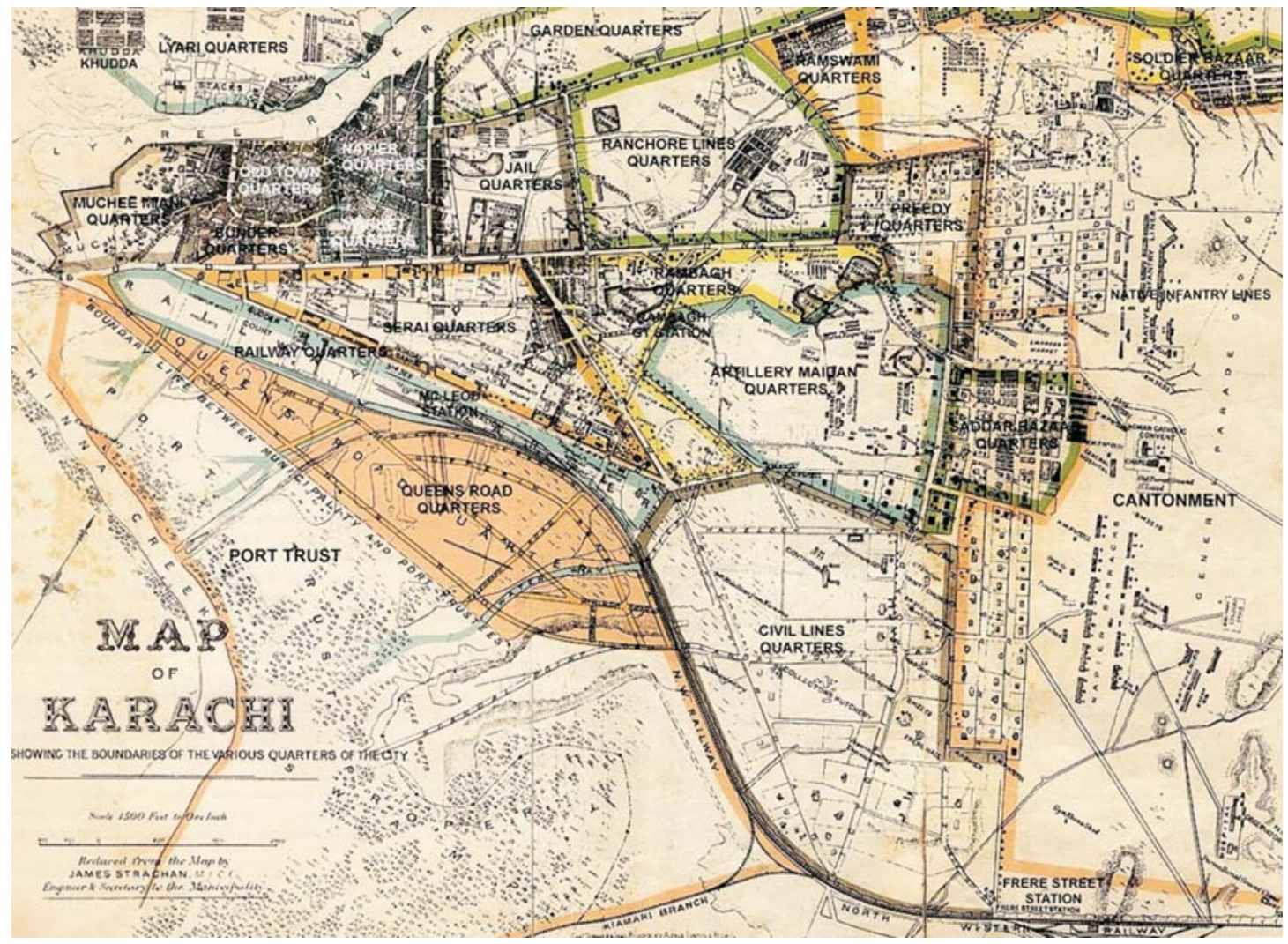

Figure 2: Map of Karachi by James Strachan in 1890Map of Karachi by James Strachan in 1890 
which connected Karachi to the rest of India, first South Asian tramway, and public building projects such as Empress Market and Frere Hall Gardens. Till 1876, the city of Karachi comprised of temples, churches, mosques, courthouses, markets and paved streets. By the late 1880's, the city was divided into 26 quarters, out of which the more important ones were Old Town, Saddar Bazaar, Garden, Jail, Serai, Rambagh, Railway, Civil Lines, Frere Town and Cantonment, Bunder, Market and Preedy Quarters.

\section{Saddar Bazaar and its Formation}

Saddar bazaar, a chief or permanent principle market was developed during this period with the intention to fulfill the requirements and needs of the wives of the British officers. It was the first major urban intervention by the British in Karachi. Thus, it was known as "Camp Bazaar" or "Regimental Bazaar", which later on got the name of Saddar bazaar. Initially Charles Napier demolished all the shops of the natives, as he believed that the natives should not have been allowed to own property in the Cantonment area. Later on, Napier allowed the natives to open shops in Saddar bazaar. Many shops were developed by the locals which lead to the emergence of the communities in the area. Some of the early risk takers were:
- Mahomed Ali Alibhoy \& Sons: Contractors for the military.

- Mohamed Ali Alibhoy Karimji \& Sons: Supply and transport works, hardware.

- T. Cossor \& Co. Engineering works and godowns.

Eventually Saddar bazaar became the most fashionable shopping area in the city. It comprised of expensive shops, which were all well stocked with imported goods. A number of shops and small manufacturers were also located along Elphinstone Street, Saddar.

In some cities of the sub-continent, these bazaars were designed as a separate quarter, as in the case of Karachi (Saddar Bazaar quarters), while in other cities these bazaar's formed the main spine of the city, as in case of Lahore (The Mall). In some cities the Cantonment bazaars were placed at the junction of main spines or roads of the city, as in the case of Rawalpindi's Saddar bazaar. Thus, these bazaar's became the recreational and commercial (shopping) zone for the whites and local elites, that influenced the overall development of the city.

- Haji Dossul \& Sons Co: General merchandising, fancy goods and ammunition.

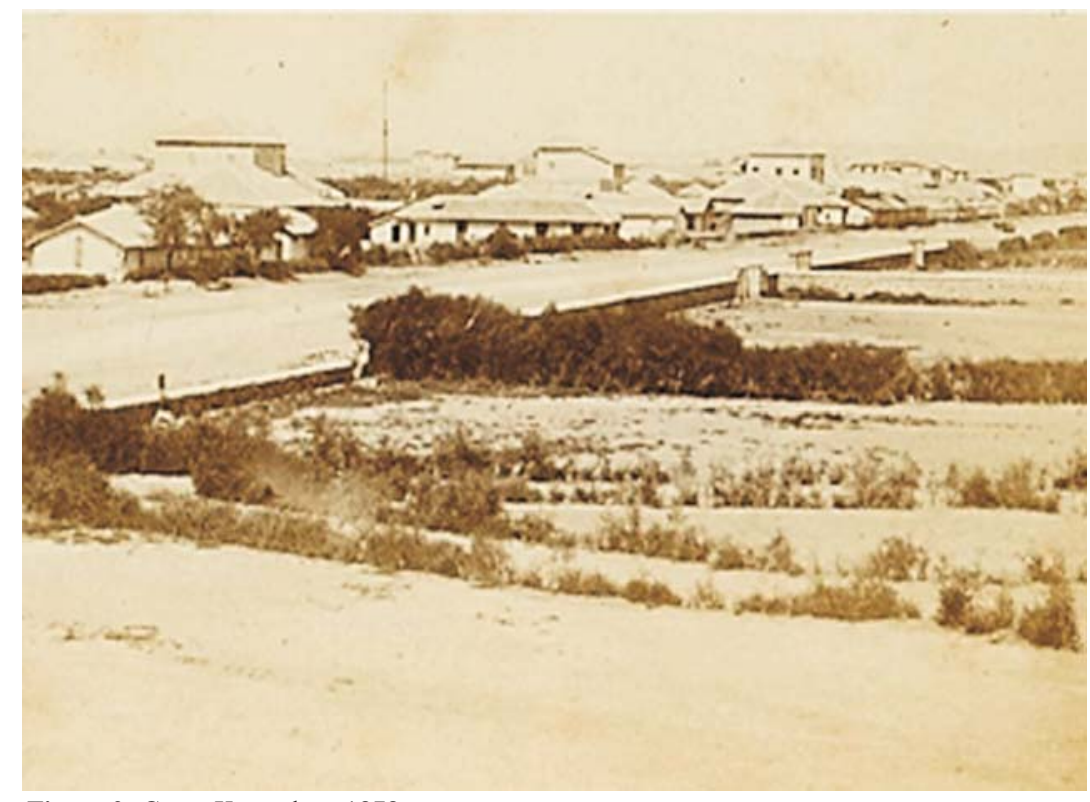

Figure 3: Camp Kurrachee, 1878 


\section{Communities and their Lifestyles}

Karachi during the $19^{\text {th }}$ century was very cosmopolitan, like all important ports and trade centres in the subcontinent. In the Saddar Bazaar, almost every Eastern nationality and caste was represented. There were Barahmins and Banyas from all parts of India, Hindus from Cutch, Rajputs from, Bombay and Madras, Mohammedan traders of all kinds from Cutch and Baluchistan including Khojas, Bohras, Arabs, Persians and Afghans, Parsis, Goans from the island of Goa and even some Jews, who also came in search of business and trade. These communities on one hand maintained their separate identities, but on the other hand influenced each other culturally and socially which resulted in a homogenized culture.

The growth of Saddar gathered momentum after the rebellion movement of 1857 against the British rule. The development was pushed through the policies of the British related to trade and commerce, and through the founding spirit of Goans, Parsis, Hindus and later the Muslim trade communities, who established businesses in the bazaar. The Hindus, who were the founders of Karachi, started their trade from the family of Naomal Hotchand. In 1947, the Hindus, numbering 180,199 was the major community of Karachi. The percentage of Hindu population was recorded at 46.6 per cent according to the 1941 census. This was because large number of Hindus from the mofussils were immigrating into the city for security reasons and for better sources of income. As traders and businessmen, Bhaiband community played a vital role in the development of Saddar bazaar. Men like Tahilram Khemchand, Udharam Wadhumal and Harchandrai Vishindas are some outstanding builders of modern Karachi. Some of the architectural edifices constructed by them and which can still be witnessed today are Shri Swaminarayan Temple, Ramchandra Mandir on Preedy Street, Ratan Talao Gurudwara and many more (see Figures 4 and 5).

The Mohemmedans also played a vital role in the development of Karachi. As per 1941 census, they were the largest minority. There were Sindhi Mohemmadens and Mohammedans from Balouchistan, Afghanistan and from Cutch, Kathiwar and other Western Indian States. Among them, the Bohras, Khojas (Agha Khanis) and the Memons have played a considerable part in the development of Karachi in terms of trade. The Ismailis who were termed as Khojas or Aga Khanis set up their exclusive Jamatkhanas. ${ }^{\text {vi }}$ They participated in the civic life of the city. Seth Ghulam Hussain Chagla played a vital role in the municipality council of Karachi. The Memons who originally came from Cutch contributed through setting

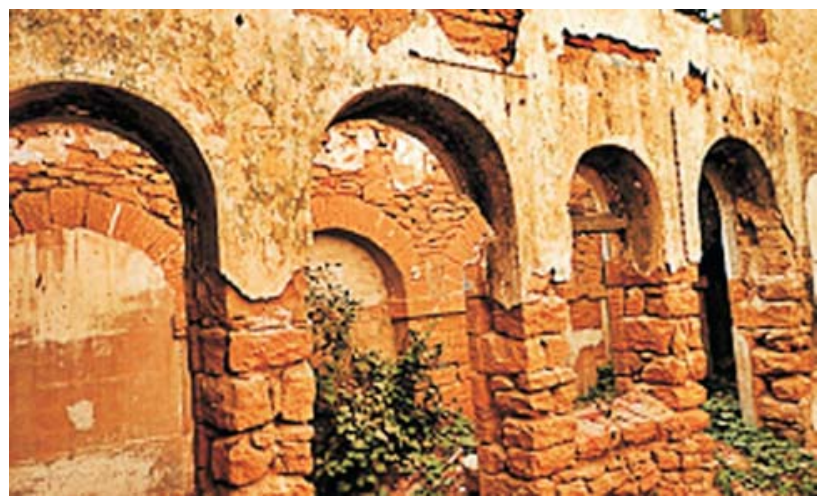

Figure 4: Ratan Talao Gurudwara

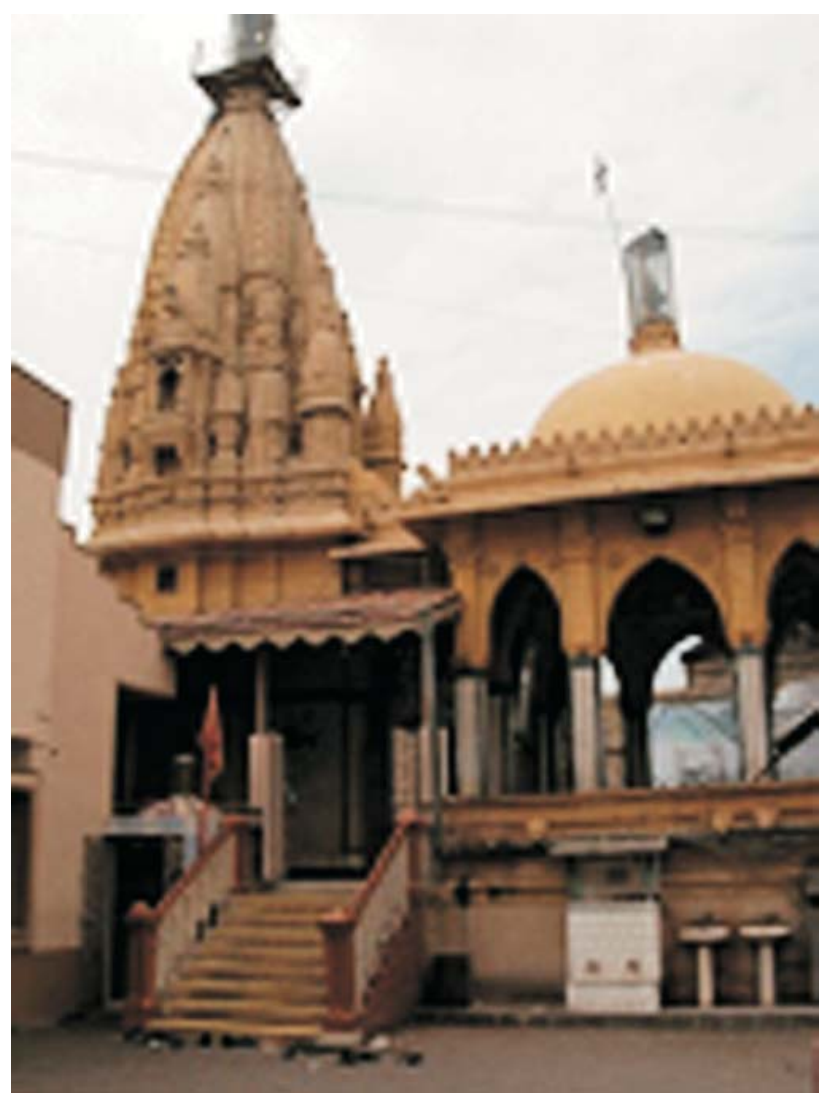

Figure 5: Shri Swaminarayan Temple, 1849

up large businesses in the city. Mr Saleh Mohammad Omar Dossa's and Sir Haji Abdullah Haroon's families typify the pioneering spirit of the Memon merchants. The Bohras, though numerically the smallest, enjoyed the privilege of very high literacy and civic sense. The Bohra family of Ghulam Hussain has disappeared, yet it is still remembered by the name 'Gibbon'. In terms of architecture, Mr Ghulam 
Hussain Khalikdina constructed the first town hall for the city. The Jaffer Fadoo dispensary is named after the Ishnaashri Khoja. Memons of Cutch, built many mosques. Cutchi Memon Mosque was constructed in 1893. Sir Haji Abdullah Haroon was a major memon activist and built many residential buildings for the memons.

The Christians constructed Roman Catholic and Protestant churches. The Roman Catholics were known as 'Goans', whereas the others were Europeans of different nationalities, the majority of them were British, English, Scottish and Irish (see Figures 6 and 7). The Protestant Church situated opposite the Government house is one of the various churches constructed by the Christian community. It was meant to serve as a landmark for mariners approaching from a distance. The Church looks more like a battlement tower than a House of God, but it holds many a sacred memory for the Protestant residents of Karachi.
Kincaid relates an amusing story about this church:

“.... General Nicholson whose name was on everyone's lips because on one occasion for a bet, he hoped from turret to turret of the Karachi's Church Tower (Trinity). The turrets were five feet apart and the tower atleast one hundred and fifty feet high",

The Goans were immigrants from different parts of India, who had made their home in Karachi. The community numbers were around 13,000 and their life was centered around their church, which was St. Patrick's and was founded in 1845 with their schools- St. Patrick's school for boys and St. Joseph Covent for girls. The Goans were mostly business and professional men. Majority of them served as clerks and domestic servants. ${ }^{4}$

The Jewish community was once an integral part of Karachi and played an important role in the city's development. The

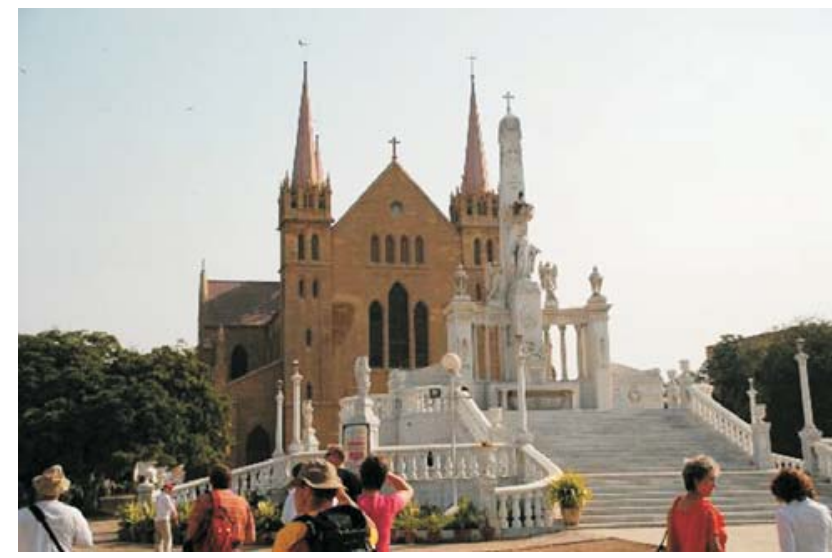

Figure 6: St Patricks Cathedral, 1901

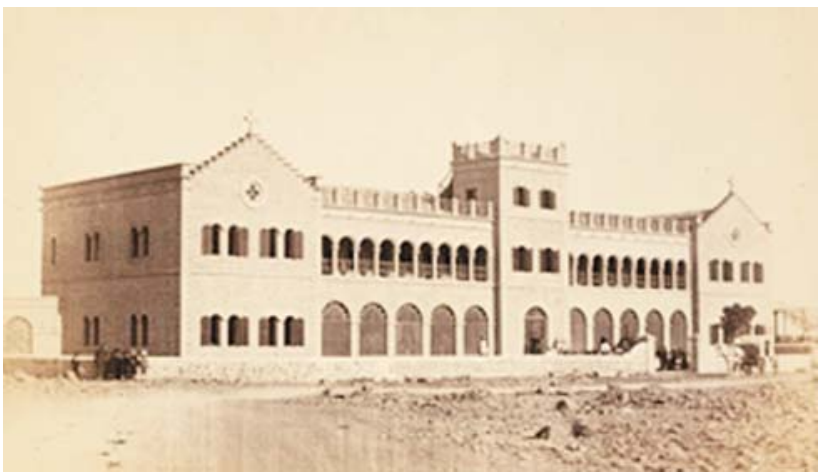

Figure 7: St Patricks School, 1873

3 Rustomji, Karachi: 1839-1947: A Short History of the Foundation and Growth of Karachi, 2007, pg 78 4 Ibid 
Jewish community mostly came from Maharashtra. The first place of worship that they built in Karachi was in 1893. A senior member of the Jewish community, Solomon David, was instrumental in setting up the synagogue called Magan Shalome (see Figure 8). He was a respected figure who held important positions, including some in the municipality. The synagogue was the centre of the community's socio-cultural activities. Another noted Karachi Jew was architect Moses Somake, who designed such buildings as the Flagstaff House, Goan Association Hall and Edward House.

Parsis, who are generally known as Zoroastrians were 'fire worshipper' who followed the ancient king of Bactria. They came to Karachi as traders, particularly as suppliers and military contractors. They settled in the most convenient locality of Saddar bazaar which was more or less in the center of the cantonment. Lieutenant Colonel Baillie of the British Army, wrote in 1890: "The number of Parsis residing in town by no means represents their importance as factors of the trade and commerce of the Port".

Montague Webb paid a glowing tribute to the community when he spoke of them in these words: "To the alert and energetic followers of Zoroaster Karachi owes perhaps more than to the members of any community". 5 Eduljee Dinshaw and his family was one of the renowned Parsi who participated in the welfare of the city and built and funded many schools, colleges and dispensaries (see Figures 9 to 11). One such dispensary is the Eduljee Dinshaw Dispensary. Jamshed Nusserwanjee Mehta was another important Parsi figure who was also elected as a member of municipal council and built the urban nomenclature of the city. Parsi Gymkhana was established by two Parsi gentlemen in 1893 to encourage sports in the community. Cricket, billiard and other popular games were encouraged in which only men were allowed. In 1899, women were given permission to enter the Karachi Parsi Gymkhana and dine there. Hormasji Ardeshir Cowasjee, was another Parsi philanthropist who was given the title of 'the guardian' to the city of Karachi and was a famous columnist, social and activist. He regularly battled with the land grabbers and raised his voice against illegal building projects in the Old Quarters of Karachi.

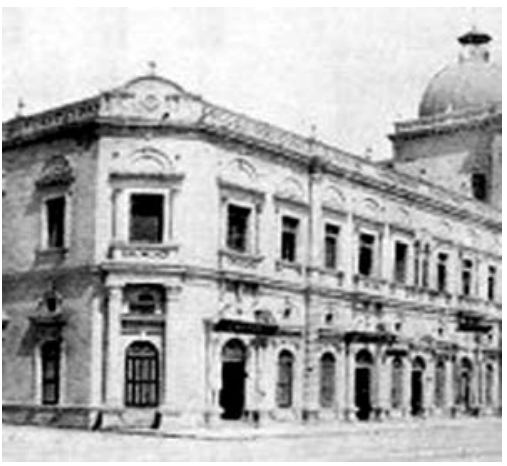

Figure 8: Jewish Community sitting outside the Synagogue

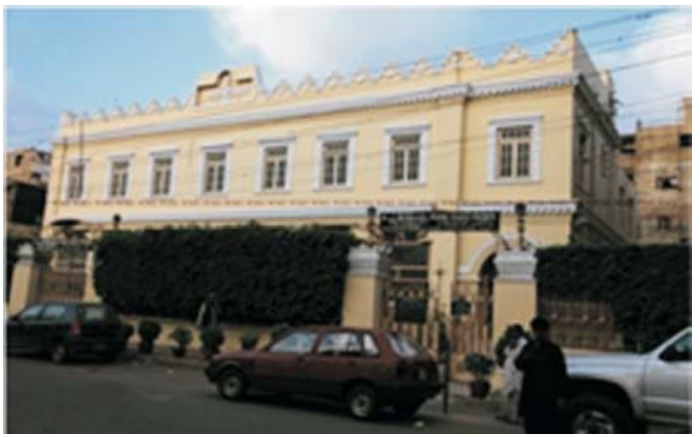

Figure 9: Parsi Dar e Meher

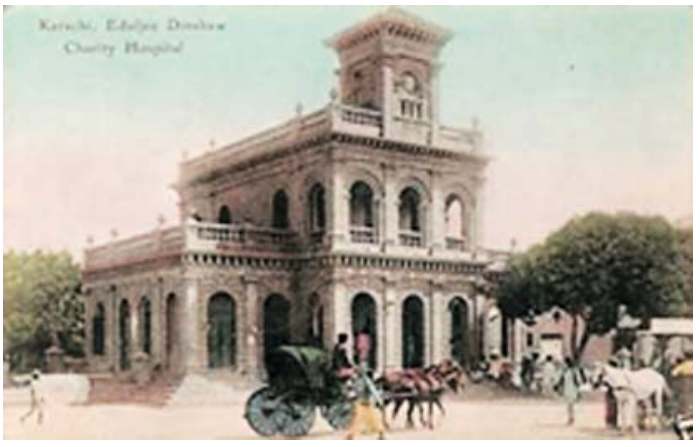

Figure 10: Eduljee Dinshaw Dispensary

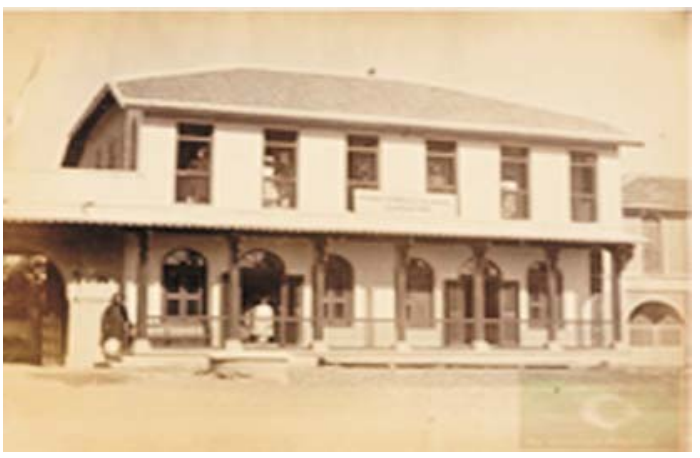

Figure 11: BVS Parsi School

5 Rustomji, Karachi: 1839-1947: A Short History of the Foundation and Growth of Karachi, 2007, pg 82-83 
Richard F. Burton states very amusingly in his book 'Sind Revisited' that:

"The Parsis have a lattices fire-temple in the bazar. The Catholics have grown a large and splendid nunnery and girl's school near the old cemetery. The Methodists have a chapel, personage and school close to the bazaar".

Saddar's Hoar \& Co. (see Figure 13) located on Elphinstone Street was considered to house the finest men's fabric collection where every department was under English control. Another fine store in Saddar was the Hayden Company which was considered as the only piano manufacturers in India at the time. They installed their first piano in governor house on 8th May, 1917. Hajee Dossul and Sons Co, was established in 1840 and housed fancy goods and ammunition. Many other famous stores and shops, such as Nusserwanjee and Co, Indian Life Insurance and Co, and Bliss and Co (see Figure 12) also opened in other streets and roads of Saddar bazaar elevating the importance of the area as well as the role played by the communities.

\section{Placement of communities in Saddar Bazaar}

Saddar was known for its business, trade and cultural activities, and was frequented by the elites and different ethnicities. In its initial development the area was dominated by the Parsis who set up many businesses in the area occupying $50 \%$ of the land at that time. With them, the Christians, particularly Goans, began working towards the provision of basic necessities for the natives. Later, Bohris played an important role in the economic setup of the area and established areas like Bohri bazaar. Imported goods from other cities were sold here. This locality also had residential areas dominated by Goans, Parsis and Europeans, who owned much of the businesses in the bazaar. The bazaar was dominated by churches, missionary schools, community halls and civic buildings owned and operated by a trust belonging to Christians (local and Europeans) and Parsis. To the southeast of Saddar bazaar were the Civil Lines and military cantonment where the British officers lived and worked and where their clubs were located. Surrounding areas were known as the European city.

The map shows the location of various communities residing in Saddar in early nineteenth century (see Figure 14).

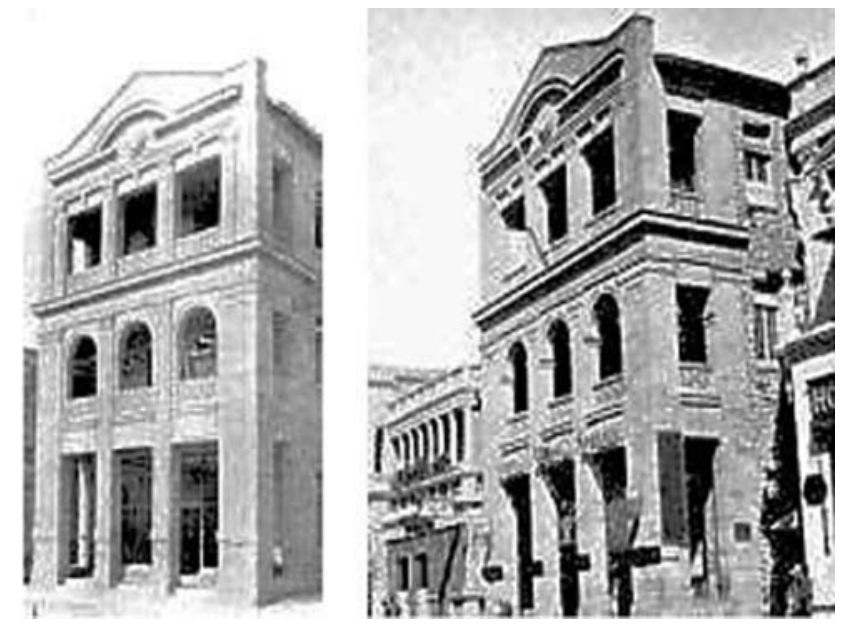

Figure 12: Bliss \&Co 1896, Saddar

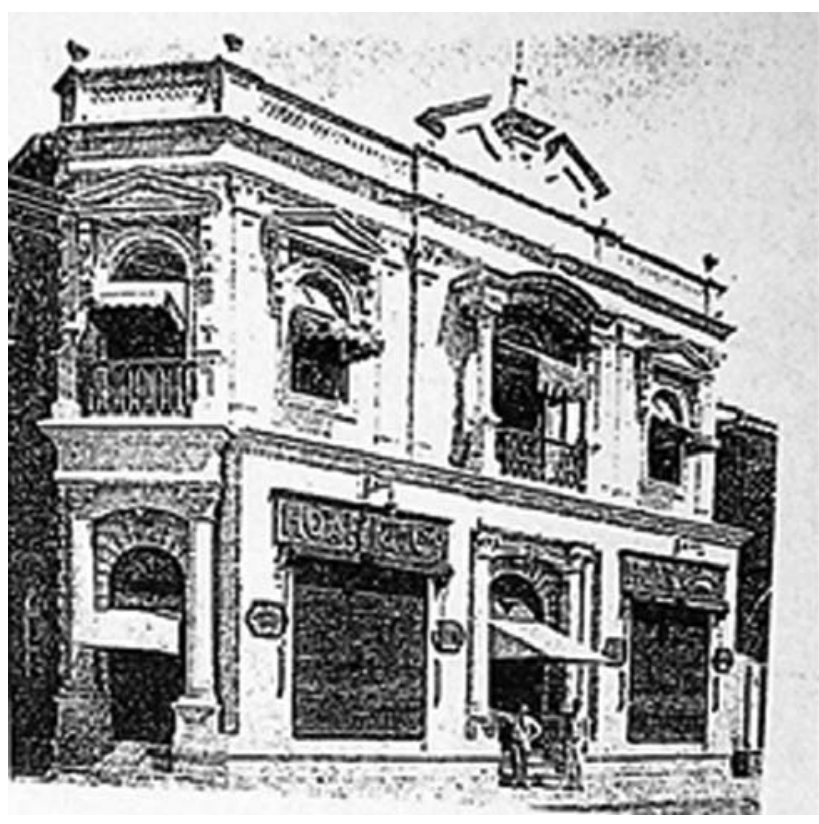

Figure 13: Hoar \& Co, Elphinstone Street, Saddar

6 Burton R. F., reprinted 1993), pg 70 


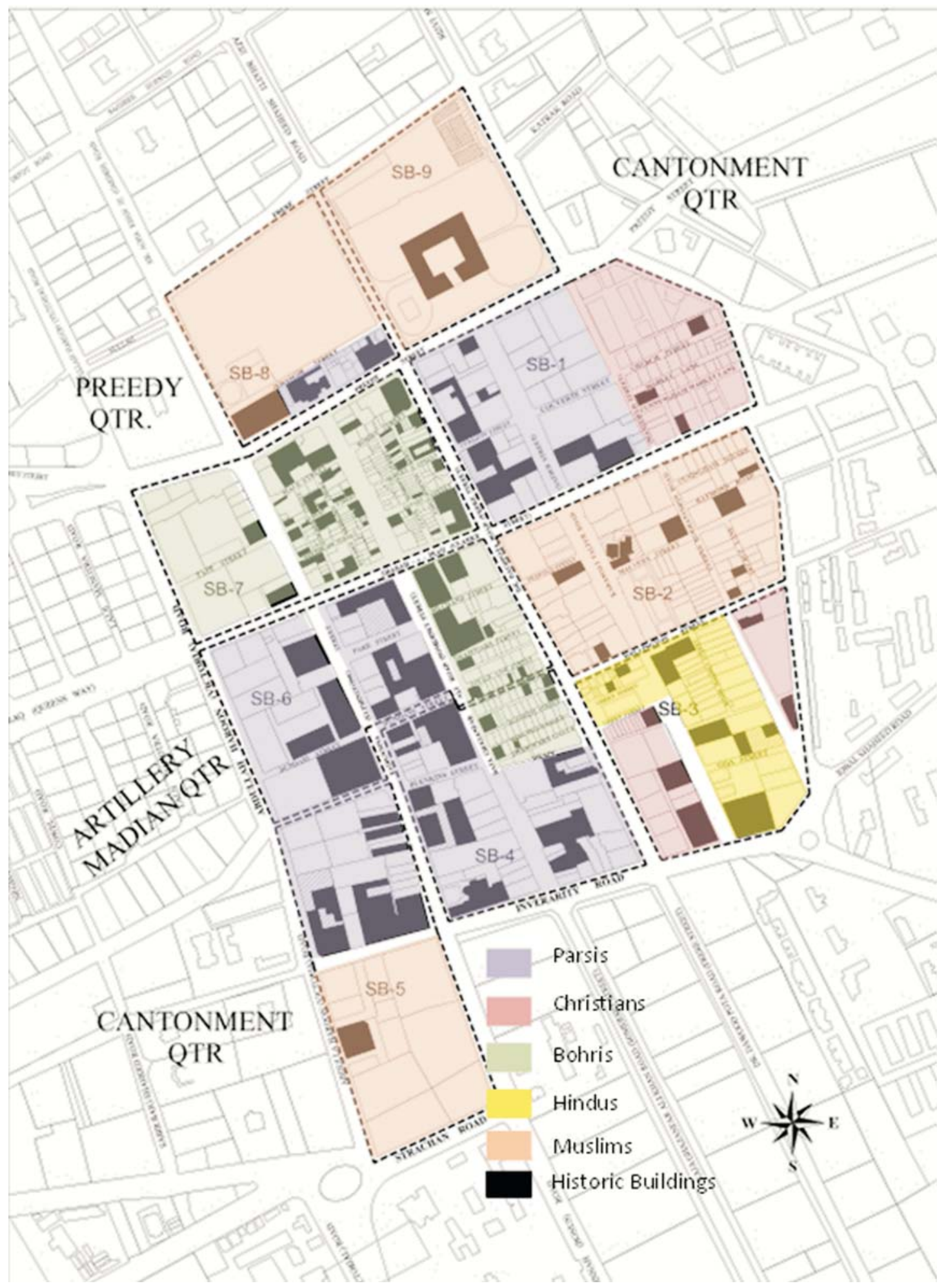

Figure 14: Map showing the location of various communities residing in Saddar 


\section{Architectural Participation by Local Inhabitants / Architects}

The local mercantile community began acquiring buildings in Zaibunnisa Street, Saddar (previously known as Elphinstone Street) in the early $20^{\text {th }}$ century. Many buildings can still be seen on this Street as examples of the adopted 'Italianate' and 'Indo-Saracenic' building style which are examples of a localized version of the western Barooque style of construction. ${ }^{7}$ The fashion of hiring professional architects and the competition between mercantile associations promoted the expression of architectural design and ornamentation in an exquisite manner in these buildings.

Jamsedji P. Mistry was a notable architect of this era and has been discovered at the Karachi Municipal Records. He practiced in collaboration with architectural and engineering firms under the banner of "Mistry and Bhedwar, Architects and Civil Engineers". The firm was active from 1917 till 1935. From the documents it is obvious that the firm was also working in Bombay, now known as Mumbai, and had its practice on the "Church Gate Street", whereas in Karachi the office was located on "New Cloth Market, Bunder Road". The architect was a Parsi, and had renowned Parsi trading families, like the Dinshaw family and the Cowasjee family, as clients. His works include mixed use and residential buildings, as well as some additions and alterations to the existing buildings. In 1920, a small structure of 120 sq.yds was constructed by the architect for Miss Emily Rozario. The structure was facing Dundas Street. This two storey building consisted of flat arches and projected balconies on both sides. Over the years the building has gone through many alterations. The building has minimum ornamentation at the corners and a rusticated band on the first floor, and reflects a classical style while the overall expression of the building is in Renaissance style. Today the building is known by the name 'Gulshan-e- Khuwaja, Gareeb Nawaz Building'.

Hassasing H. Advani was another architect and civil engineer who worked in Karachi in the first quarter of the twentieth century. His work includes institutional, commercial and residential buildings that were built in various Quarters of the city. In the last decade of the nineteenth century, a designer who made his appearance in Karachi was Moses Somake. He handled many important commissions and was a famous member of the Society of Architects. He was born in Lahore and had Jewish origins. It is not known whether he was a trained architect or not, but in the 1913 Karachi
Handbook, his firm is listed as "Architects, Surveyors and Contractors, Victoria Road" under the "Mercantile and Professional". Another entry under Trading Firms, mentions 'M. Somake Company' as 'Agents for Belgium Compressed Cement and Floor Tiles, Manufacturers of Artificial Stones for Plain, Reinforced and Architectural Works'. The major project which he handled in Saddar bazaar was the Goa Portuguese Hall, also known as Goan Gymkhana, in 1905. The handling of the volumes in this building reflects his seriousness towards the project. Renaissance was the style chosen by Somake. The exterior consists of the pedimented centre with hipped roofs and dormers. The semicircular window openings with circular dormer windows and elaborate pilasters show his inclination towards the Classical European style of architecture. The interior of the building is quite elaborate, with Belgian tiles used on the ground floor and teak flooring on the first floor hall. The interior spaces were designed with perfect proportions, creating a feeling of loftiness and spaciousness.

During this period, there were many local businessmen and traders who constructed buildings on their own, without hiring architects professionally. These local designers and craftsmen were skilled in creating a mix of imported styles and local elements, which formed hybrid structures. Some of them were ornate and simple but were inspired by the influences brought by the British rulers. "The architectural expression which could be termed the "Hybridized -Classical Style" contained elements that drew inspiration from European Classical forms but were intermingled with indigenous motifs giving local color and charm, without sacrificing the inherent expression of imperial grandeur". ${ }^{8}$

The first street which got an element of grandeur was Elphinstone Street (now Zaibunnisa Street), which acquired many mercantile structures. Nusserwanjee R. Mehta, a Parsi trader built an impressive two storey building at the corner of Elphinstone and Dundas Street with Classical features. The use of tall pilasters with the pediment on the roof and decorative balustrading enhanced the beauty of the building. Another mercantile trading firm was Haji Dossul and Sons, which was established in 1840 . They also acted as army contractors and auctioneers. The firm constructed a department store named Mohammad Ali Building, which is situated in the vicinity of Nusserwanjee Building. The building shows its grandeur with its large, well-modulated façade. Features such as Roman arches, triangular pediments, coupled Venetian windows, Corinthian pillars and carved 


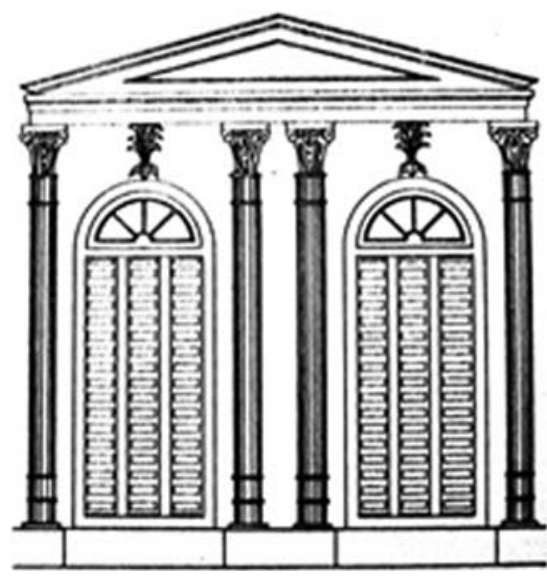

Figure 15: Details of Window Openings
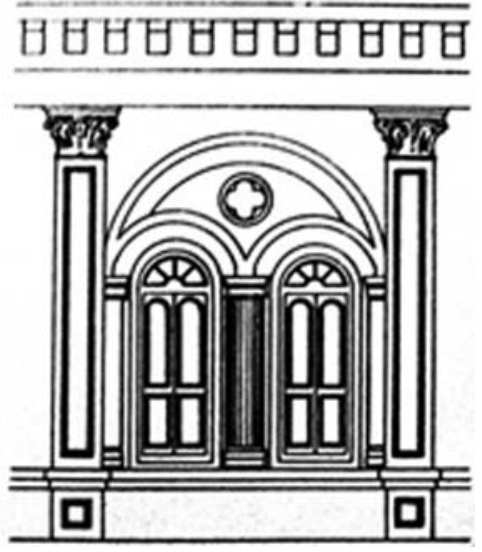

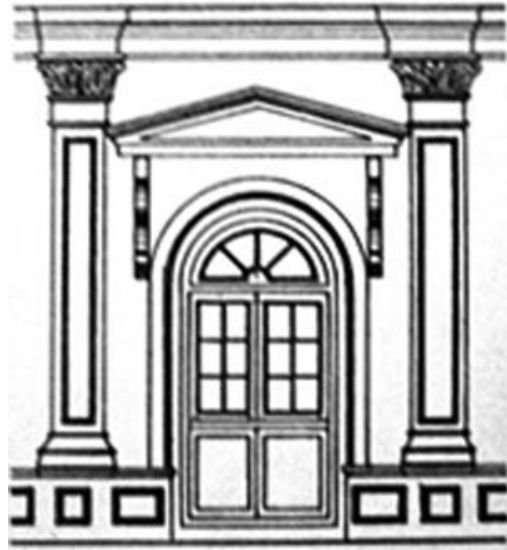

Figure 16: Treatment of Openings- Roman arches, Pilasters and Pediments balusters show that the building was constructed in Classical style (see Figures 15 and 16).

One of the piano manufacturers and importers of musical merchandise, The Hayden Company also opened their shop on Dundas Street, now Victoria Furnishing Mart. The building consists of rusticated pilasters on the ground floor with semicircular arches. On the ground floor there are ventilators which are also semi-circular in shape and are mounted by large beautifully carved keystone. The upper storey has projected balconies supported by stone brackets. The building was originally built in Gizri stone.

The Old Ilaco House, an outstanding edifice standing on Elphinstone Street was constructed by the Indian Life Insurance Company Ltd. Majorly, it consisted of a central porch emphasized by the dome in the centre with intricate round arches on first floor embellished with a projected balcony. The ground floor had broken pediments, whereas the first floor had semicircular pediments with intricate carving.

Other mercantile firms were Adam Soomar and Co., which served as bakers and confectioners, and developed their shop on Frere Street.

Ardeshir Hormusjee Mama, a transport agent constructed Mama Mansions, now known as Jehangir Kothari building. Saddar Mosque was also known as Jama Masjid mosque, and was constructed in 1900 with pure Italian Renaissance features. The mosque was multilevel with simple arcading and projecting string courses to define the floor, and the roof and the capitals incorporated local motifs, making the character of the building hybrid. Parsi Dare Meher Fire Temple, which was once known as Camp Agiary, was built in 1875 by the trust of Seth Hirji Jamsheji Behrana. This was a two storey structure, with the emblem at the top is an eclectic style. The upper storey was added by Mistry and Bhedwar later. The building was characterized by semicircular arches at the ground level whereas the upper level consisted of apartments with intricate parapet details.

\section{Analytical Review- Case studies in Saddar Bazaar}

During the British reign, the architectural forms established were based on pure aesthetics, containing geometrical manipulation with well-devised architectural ornamentation. 1900s saw the engagement of many local philanthropists in the construction activity of the city. An analysis shows that there are two ways in which these buildings were designed, either through the hiring of a foreign architects or engineers or by local designers. Most of the buildings designed by foreign architects/ engineers were for public use, whereas the buildings designed by local designers were the business houses which were constructed for family businesses. The case studies shortlisted here, help further understand the contribution made by the communities in the building construction during the early $19^{\text {th }}$ century. The cases of Mohammad Ali building (a business house built in 1840) and Krishna Mansion (a residential cum commercial building built in 1919) are taken.

Mohammad Ali Building (see Figure 17) was designed by the local designer, as most probably the very first business house in the early $19^{\text {th }}$ century. The building once belonged to a rich ammunition dealer Haji Dossal, and was constructed as a department store in 1840. The ownership was transformed to a Tram Service owner, Mohammad Ali who bought it in an auction and thus named it as Mohammad Ali Building. The building was located on main Zaibunnisa Street. The 


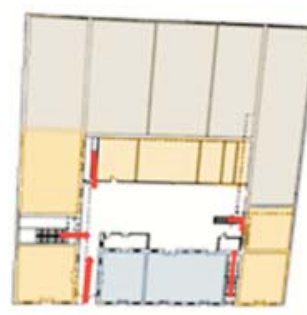

Present

Use G.F

Banks

Shops

Godowns

- Circulation

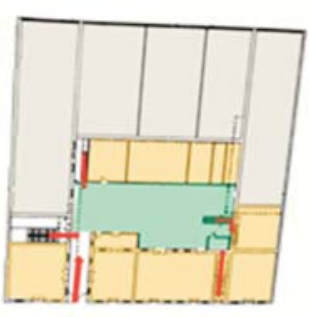

Original

Use G.F

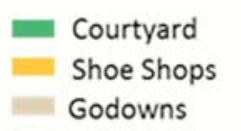

- Circulation

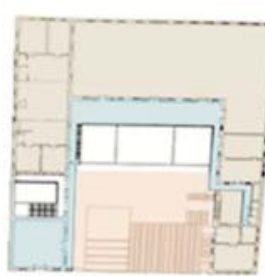

Present

Use F.F

Vacant

Terrace

Demolished

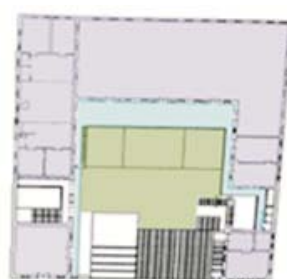

Original

Use F.F

Apartment

Terrace

Courtyard
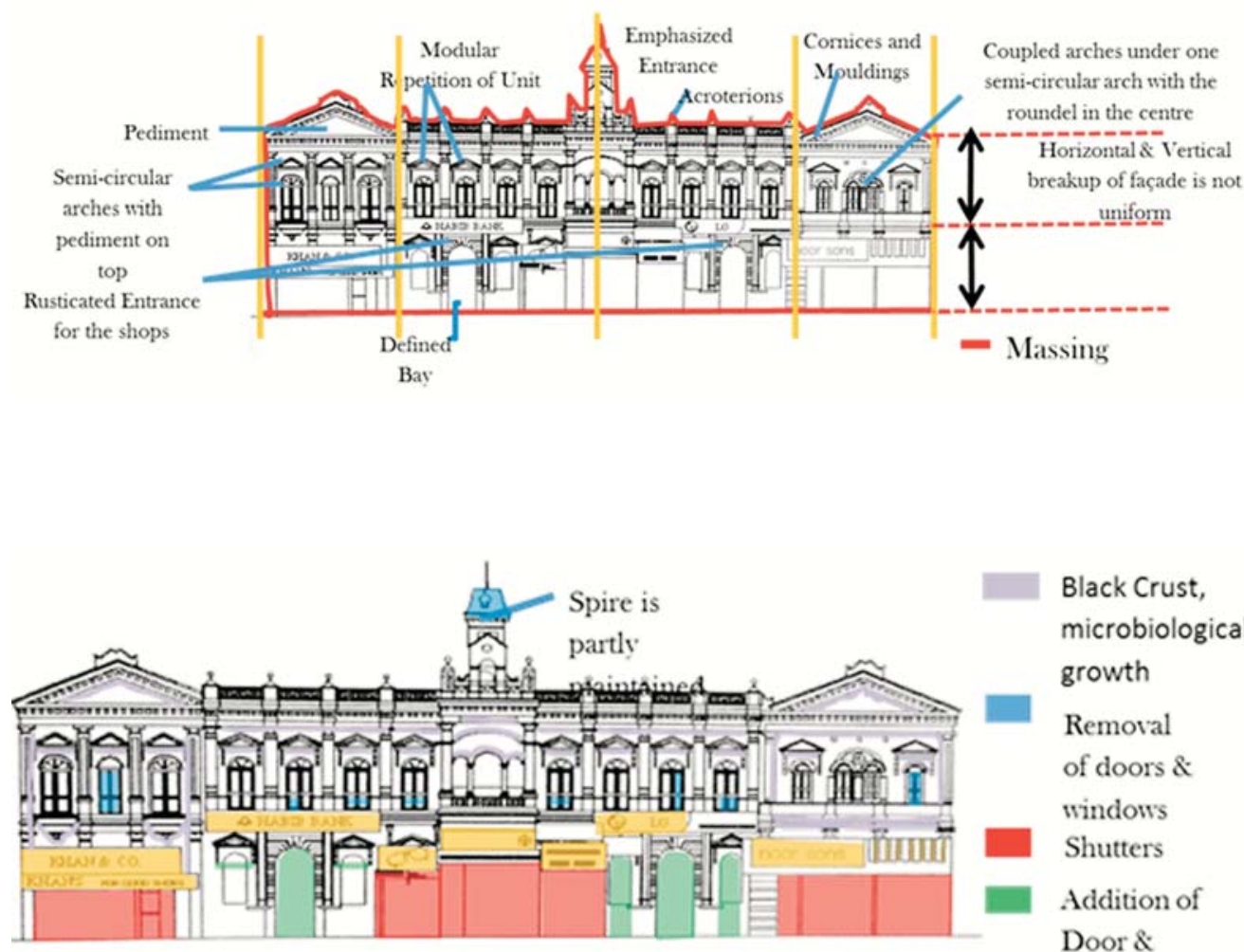

Black Crust, microbiological growth

Removal of doors \& windows Shutters Addition of Door \& Chaijas

Addition of Signboards

Figure 17: An architectural analysis of Mohammad Ali Building 
plot had three sides, one side faced the main road, and the other sides faced secondary streets. This building stands till today and two entrances can be observed, the main road access leads to the shops and the other entrances lead to the courtyard and the upper floors. It has a strong presence in the neighborhood with its large and well-modulated façade. The front of the building is given to the shops; the warehouses /godowns are located at the back. Both the shops and warehouses are surrounded by a central courtyard, which acts as a breathing space for the building. The access to the warehouse is from the rear of the building, via a narrow lane. The plan of the building is square in shape, with rectangles inside forming rooms for shops and warehouses. The structural system of the building is load bearing, with 1 '-6" thickness of walls. Some of the walls for warehouses were 7" thin. The beams and columns are situated on a grid. The building exuberates good workmanship which is the result of carefully selected materials. The material primarily used in the building is lime stone, reinforced cement and concrete, wood, iron, marble and glass. The building façade is decorated in stone and cut stone is used for the rear. The building has balanced proportions. The timber pitched roof has red terracotta tiles (khaprail). Presently, the roof on the right side of the building is in a dilapidated condition, while on the other side of the building, the roof is still intact.

Mosaic flooring of different unique patterns was one of the features of this buildings. The floors for the warehouses were cemented with grooves, which gave a tiled look and was rough in surface. The external arched openings consisted of louvred paneled doors with the colored glass panes (orange, blue and green) fixed in the semicircle of an arch. These doors opened in a small balcony space. The external windows also had louvres, with one fixed panel at the bottom. The internal door openings consisted of paneled doors each hinged from the centre. The internal window openings consisted of paneled sashes with colored panes fixed from inside. This building had a variety of external architectural ornamentation. The main focal point of this building was its spire or bell tower which was placed at the centre. This tower consisted of intricate details, such as modulated moldings, cornices with the roundel in the centre surrounded by a star or flower and an arched opening followed by curved bracket lines on both sides. The centre of the façade consisted of a jharoka style balcony, which was decorated with Corinthian pilasters. Pediments were placed on both front sides of the building and on every opening, which enhanced the beauty and grandeur of the building. Cone style balconies on upper floors were carved by the artisans.
The building has a stone foundation. This is one of the major reasons why the buildings is still intact, even after several years.

Krishna Manzil / Mansion, (see Figures 18 and 19) is a project which was taken by Advani, an architect and civil engineer of the early $19^{\text {th }}$ century and is located in Saddar bazaar. This is the most striking building designed by Advani, that also happens to have survived the ravages of time. The locality by that time had developed from purely commercial to a prestigious commercial cum residential area, mainly occupied by the 'natives'. It boasts of a 101 feet wide frontage, with a generous area of over 9,000 sq ft. An imposing three-storey mixed-use structure, Advani's tour de force dominates the Dundas Street with its eclectic mix of architectural features. Several plans with minor revisions have been found in the archives, however, the final layout approved by the Acting Engineer Karachi Municipality is detailed out exquisitely.

The building is symmetrical in plan and is based on a grid pattern. The staircase, which helps to access the upper floors, is slightly off-centered. The building is organized with three shops of equal size on ground floor, which can be accessed through the main road. The upper floors can be accessed through the staircase, which faces the main road. The upper floors are designed in apartment style residential units. Each apartment consists of a living room, kitchen, and a bedroom with dressing and bathroom. There is an air well, which is off centered, measures 14'3" and acts as a breathing space for the building. There is a staircase at the rear end of the building, which opens into a 4' narrow street. This staircase was used by the domestic servants. The external window openings at the ground floor are round arches, which are embellished in rusticated stone. The other openings are the doors with flat arches. On top of them, three small ventilators are placed, with the central ventilator designed as an arch. The first floor consists of bay windows on either side of the entrance with a broken pediment on top. There are also elliptical arches, which serve as window openings. Wooden louvre blinds are arranged beautifully around the window. The entrance tower has a window with a pediment on it. The second floor is similar in plan to the floor below, except for the opening in the entrance tower. A round arch with a decorative wreath atop replaces the pediment. The side façades of the building have bold roundels which serve as ventilators for the shops and godowns. The architectural vocabulary of the building is bold with minor touches of intricacy in the design of the stone. The designer has played with the openings, using different sized openings. The use of giant piers, slightly projecting window bays crowned 
with pediments, projecting balconies and ornamental stone balustrading at the roof level, all add to the beautification of the building façade. There is a roundel at the top of the entrance with the female statues on each side. Whereas the other side of the building, which has rusticated round arches at the ground floor, is topped by a broken pediment and has a acroterion placed in the center. These acroterions were an inspiration of a crown, which is topped by the finishing element filled with jewels. There are balconies with iron grill work, supported by brackets. The pitched roof with terracotta tiles is placed on trusses inside the building. Timber wood was used to make these trusses and to frame the roof. Mosaic floors were observed in upper floors, whereas pigmented tiles were seen at the ground floor. Local Gizri stone was used for the construction. All the architectural ornamentation was done with stone carvings.

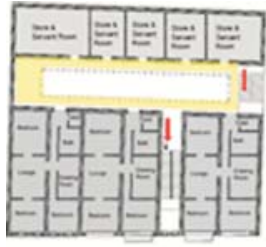

Original Use

(F.F)

Store \& Servant Room

$\Rightarrow$ Entrance

Apartments

Circulation

Path

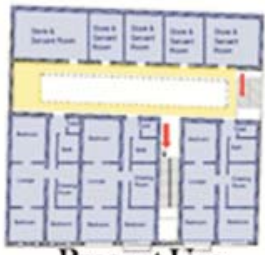

(F.F)

$\Rightarrow$ Entrance

Warehouses

Circulation Path

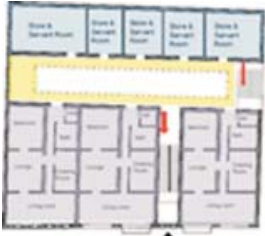

Original Use

(S.F)

- Store \& Servant Room

Inartments

Circulation Path

$\Rightarrow$ Entrance

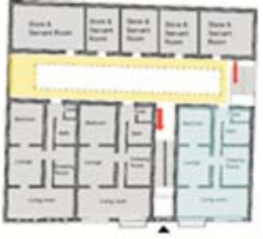

Present Use (S.F)

Vacant

Demolished

Circulation

Path

$\Rightarrow$ Entrance
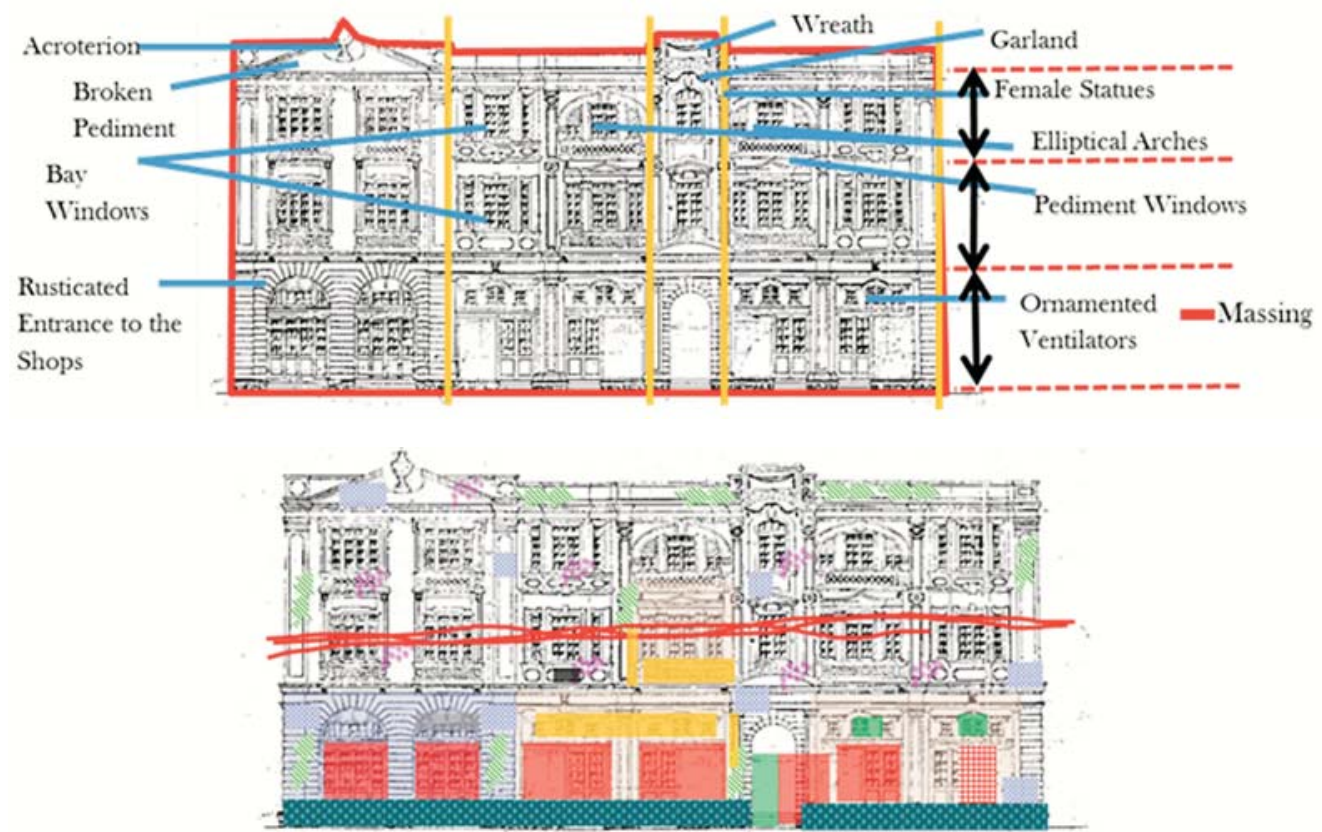

\begin{tabular}{c|lll} 
AC & Shutters & $\begin{array}{l}\text { Addition of Door } \\
\text { \& Windows }\end{array}$ & $\begin{array}{l}\text { Addition of } \\
\text { Signboards }\end{array}$ \\
Water table & Soiling \\
detention & & $\begin{array}{l}\text { Electric } \\
\text { Wiring }\end{array}$
\end{tabular}

Figure 18 \& 19: An analysis of Khrishna Manzil / Mansion. 
Some of the key points that can be summarized with regards to buildings of the early $19^{\text {th }}$ century in Saddar bazaar are that there was symmetrical planning for almost every plot in Saddar bazaar. The plot was oriented to catch westward winds through ventilators and windows which ensured natural ventilation throughout the building. Features like balconies, terraces and open outer corridors were common. The internal spaces were usually divided according to different functions and their type of usage i.e. private, public or semi-public. The central access to the building was always clearly defined.

\section{General Ornamentation in Local Forms}

When different communities started to build structures in the city, most importantly in Saddar bazaar, the architectural vocabulary of different features changed in terms of proportion, scale, and size. Sometimes these features were sophisticated and sometimes they were gauche in character. Roundels, openings, pediments, parapet, central building entrance, molding bands, pilasters, balconies, arches and other motifs were seen in variety and were applied on the buildings by different communities in Saddar bazaar (see Figure 20).

Roundels/Rosettes were used in many building designs. Sometimes they were used as decorative features, and were carved inside with motifs, and sometimes they were used for ventilation purposes, embellished with intricate geometric ornamentation (jali) in the centre. They were mostly placed between or above the window openings. In some cases, they were used as window openings as observed in Krishna Mansion.

Pediments were also a part of the architectural ornamentation and were used as a decorative feature, placed above the window or door openings. In some cases, pediments were used to enhance the entrance portal. Pediments of two types were observed in Saddar bazaar i.e. triangular pediments, which were commonly used, and the broken pediments. Examples are found in Old Ilaco House (Indian Life Insurance Company Ltd). The window openings also varied in the buildings of Saddar bazaar. Sometimes louvre openings were used, in some cases there were intricate trellises placed as openings and at other times colored glass was observed, which were equipped with window sashes.

A wide range of balconies also became a common feature for many buildings built during this period. Semicircular balconies, forming a cone shape or rectangular balconies were observed. Some of these balconies were supported
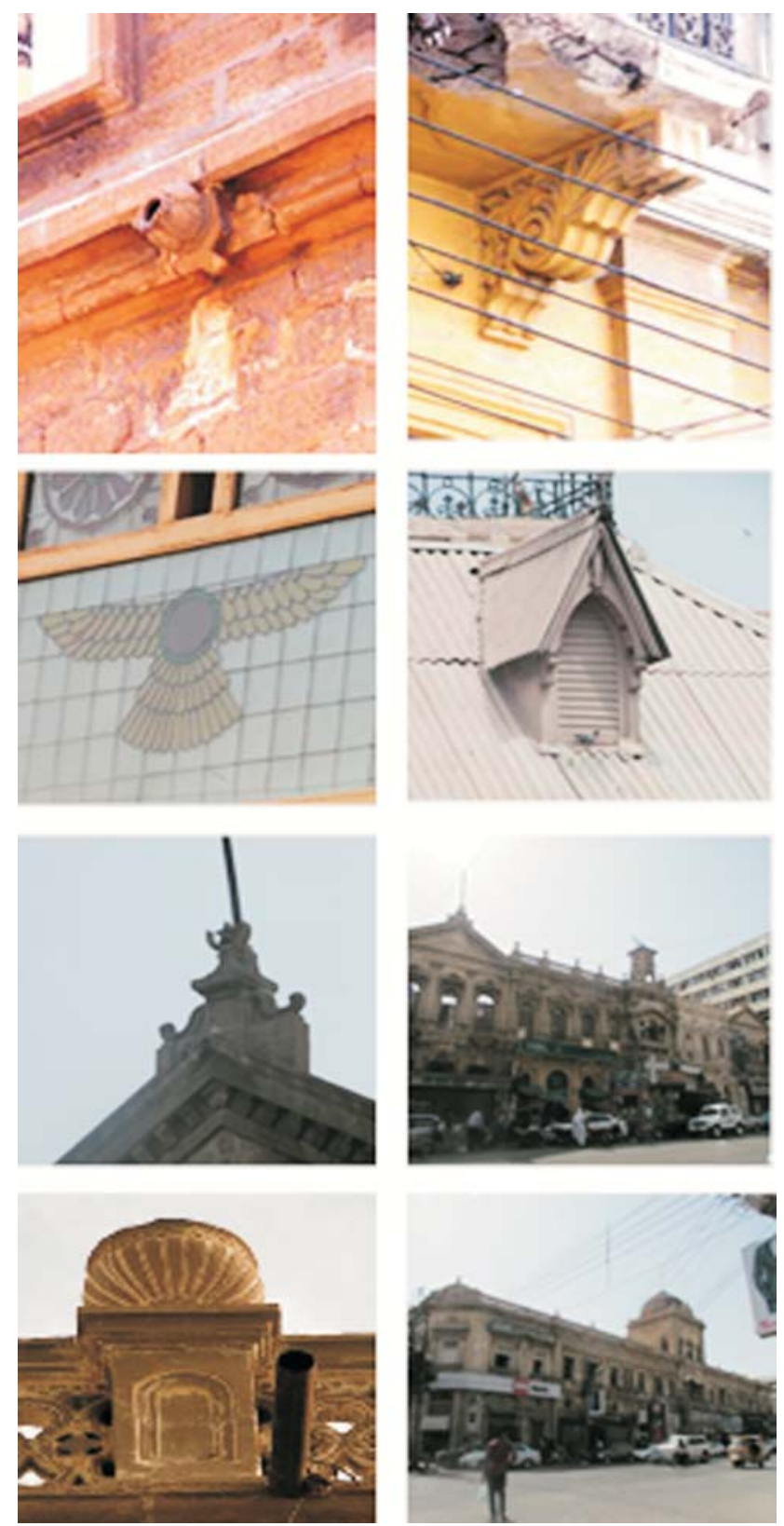

Figure 20: Samples of Other Features

with brackets, whereas others were made in stone or embellished with iron grillwork.

Moldings were a commonly used feature, which provided horizontality to the building. With these moldings, some of the geometric bands or motif bands in stucco were also observed. The moldings were different in proportions for every building. 
The other common design element in these buildings was the central entrance, that served as a portal embellished with intricate design to emphasize the entrance. Most of these entrance portals were within the building itself. The examples of such entrances can be seen in Empress Market, Edulji Dinshaw Building and many others. Parapets were an essential part of every building, especially for residential and business buildings. A large variety of designs and materials was seen in the decoration of the parapet. This included the use of stone balustrades in some cases; ornate iron grills in other cases, stucco plaster decorations and geometric patterns with void in stone in still other cases. Pilasters were extensively used in stone construction. This feature was used to break the monotony of the external horizontal walls of the buildings, and divide them into smaller panels tied with the cornice band. Arches on the other hand played a vital role in balancing the horizontal and vertical proportions of the buildings. As community participation increased, numbers of different arches were used as openings to the buildings. This included, semicircular, elliptical, pointed and shouldered arches. Other features included garlands and festoons, stucco ornamentation, statues, pitched roofs and Doric and Corinthian columns.

\section{CONCLUSION}

Karachi, has no historical roots in terms of architecture, except for the indigenous built forms constructed by the locals. British annexation gave a turning point not only in terms of commerce and trade, but also in terms of the city's architectural and urban development. The British, in order to exert themselves built a strong administration, and made Saddar bazaar the city centre, and invited the communities to participate in the progression of the city. These communities built many structures in hybrid style, and created a new architectural vocabulary for the city. A Parsi trader $\mathrm{Mr}$. Jalpowala ${ }^{\text {vii }}$ who came from Bombay said in one of the interviews, "no one really cared about the caste, religion and race at that time. Under one roof all were same and humans and nothing else". This approach facilitated the constructed of built forms which were sometimes inspired by the British and sometimes driven by hybrid or local vocabulary. The architectural features were experimented with in different ways by the local and foreign designers. It is observed that as the designers from the communities were not professionally trained architects, they took any element of ornamentation for their buildings and gave details to the hired designer or architect. The internal planning remained the same, with the entrance portal mostly in the centre with rooms or shops on each side and verandah in the middle, which was essentially the way British planned their buildings. Many architectural master pieces were thus experienced in Saddar bazaar.

Today, Saddar bazaar is in a delipidated condition due to pollution, traffic congestion and land issues (see Figure 21). The buildings might seem to be in good condition externally but internally they are facing partial deterioration. As for communities are concerned, except for the Bohris, Christians, Parsis and Muslims, all other communities chave moved out of Karachi. If appropriate revitalization steps are not taken, the precious architectural assets of Saddar bazaar will fade away, just like the communities that once flourished here.

By analyzing the different threats that Saddar bazaar faces today, two things seem to be interlinked i.e. commercialization on one hand, and on the other, community and architecture. After 1947, commercial and political pressures disturbed the sociological profile of the area. With the migration of communities from India in large numbers, all open spaces in Saddar which were previously used for communal gatherings were occupied, which led to deterioration of the sense of community. Later on, with the increase in business and trade activities in Saddar bazaar, and the involvement of land mafia, the area experienced vandalism and the communities were threatened, which further weakened the cultural dynamics of the area. With the worsening law and order of the city, personalized attacks were experienced by different ethnicities. These factors led the communities, mostly Parsis and Christians, to move out of the area, and in most of the cases, out of the country. They would then just return occasionally to attend religious ceremonies. ${ }^{\text {viii }}$

The above-mentioned aspects of cultural and social decline led to the deterioration of historic fabric in the area. Eventually the different ethnic groups left their living and trading spaces, and these buildings were subject to unchecked commercial activities which badly damaged the buildings. Only 5\%$10 \%$ buildings in Saddar bazaar today are well maintained, whereas $50 \%$ to $60 \%$ buildings are partially maintained and $20 \%$ to $30 \%$ buildings have been partially demolished and for some of the buildings only the facades remain. The societal values are very important for any city and play a vital role in the evolution of a city. Although, today the condition of Saddar bazaar is quite fragile, but these architectural assets can be protected through proper guidance and management plans. 


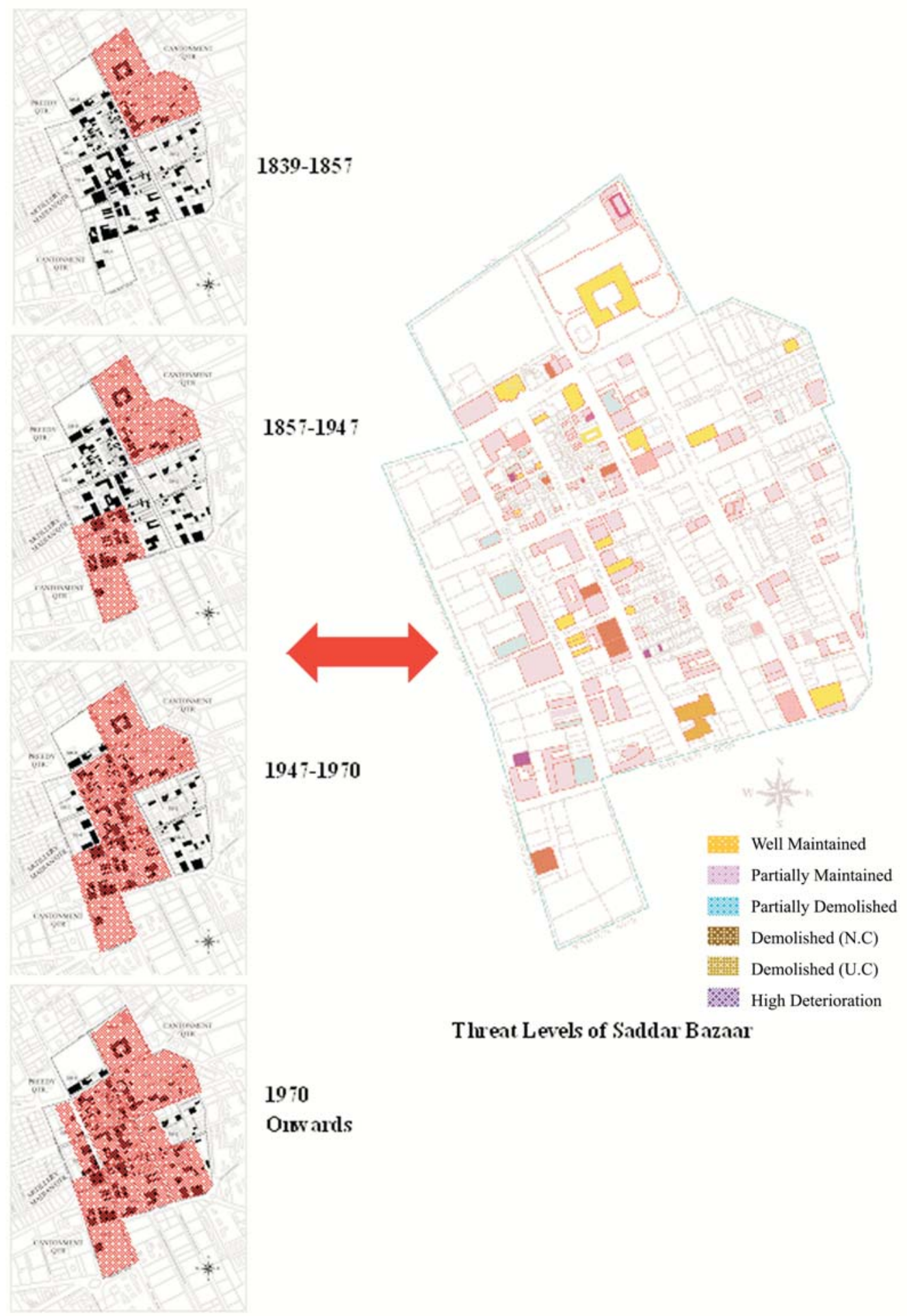

Figure 21: Threat levels of Saddar bazaar 


\section{REFERENCES}

Aitchison, C. (1865). A Collection of Treaties, Engagements and Sunnads relating to India and Neighboring countries (7th ed.). Calcutta: O.T. Cutter, Military Orphan Press.

Ali, M. (n.d.). Karachi: Living City, Dying Culture. Editor, Tarikh e Lahore .

Ansari, N. (1997). Karachi: Edge of Empire: Jewels and Gems of Raj Architecture. Lahore: Ferozesons (pvt) Ltd.

Arif Hasan, A. S. (2008). The Hawkers of Saddar Bazaar: A Plan for the Revitalisation of Saddar Bazaar Karachi Through Traffic Rerouting and the Rehabilitation of Its Hawkers. Karachi: Ushba Publishing International.

Baillie, A. F. (1890). Kurrachee: Past, Present \& Future (Volume 1 ed.).

Brown, R. (2010). THE BRITISH EMPIRE IN INDIA. Ashbrook Statesmanship Thesis.

Brunton, J. F. (1913). Karachi. Journal of the Royal Society of Arts , 61 (3148), 477-499.

Burton, R. F. (reprinted 1993). Sind Revisited (I \& II ed.). Karachi: Indus Publication.

Cheema, Y. (2008). he Historical Quarters of Karachi. Oxford University Press.

Haider, A. (1971). History of Karachi: With special reference to Educational and Commercial Development. Karachi.

Hamida Khuhro, A. M. (1997). Krachi: Mega City of Our Times (1st ed.). Karachi: Oxford University Press.

Hasan, A. (1993, February 2). The Changing Face of Karachi. The Herald .

Hassan, A. (1986). A Pedestrian Saddar. Herald .

Hassan, A. (2011, June 27). Arif Hasan. Retrieved October Tuesday, 2014, from www.arifhasan.com

Hughes, A. (1876). A Gazetteer of the Province of Sind. Londen: George Bell \& Sons.

JIAI. (1886). Journal of Indian Art and Industry, 1 (8).

Kamal, A. (2013, August). Dawn. Retrieved May Monday, 2015, from http://www.dawn.com/news/1038269

Mumtaz, K. K. (1985). Architecture in Pakistan (1st ed.). A Mimar Book.

Napier, L. G. (1995). History of Sir Charles Napier Administration of Scinde (1st ed.). Karachi: Indus Publications.

Napier, L. G. (1857). The History of Genral Sir Charles Napier's Conquest of Scinde (2nd ed.). London: Charles Westerton, Hyde Park Corner.

Nayar, P. K. (2009). Days of the Raj: Life and Leisure in British India. India: Penguin Books.

Neil, J. M. (1845). Recollections of Four Years Service in the East with H.M. 40th Regiment (1st ed.). original from Michigan: R. Bentley.

Nilsson, S. (1968). European Architecture in India 1750-1850. London: Faber and Faber, 24 Russell Square.

Papers, P. (1838-1843). Correspondance relative to Sind. In p. t. Majesty (Ed.), Napier to the Ameers of Hyderabad. London.

Parliamentary Papers relating to Sind (1838-43).

Rashidi, P. A. (1995). Wo Din, Wo Log (1st ed.). Karachi: Aaj.

Raza, F. A. (n.d.). Karachi City. Retrieved August Monday, 2015, from http://karachiciti.blogspot.com/ 
Raza, F. A. (n.d.). Karachi City. Retrieved November Monday, 2014, from http://karachiciti.blogspot.com/

Report, D. A. (2014). Scottish Architects. Retrieved December 6, 2014, from

http://www.scottisharchitects.org.uk/architect_full.php?id=202059

Rustomji, B. S. (2007). Karachi: 1839-1947: A Short History of the Foundation and Growth of Karachi (2nd ed.). Karachi: Oxford University Press.

Salman, M. (2009). Dawn. Retrieved December 3, 2014, from http://www.dawn.com/news/880631/like-a-prayer

Salman, P. (2013). Role of Jews in Karachi Uplift Highligted. Karachi: Dawn.

Siddiqui, A. H. (1996). The Pearl of Arabian Sea. Karachi: Fazel Sons Pvt Ltd.

Smith, J. W. (1919). Gazeteer of the Province of Sind (Volume 1 ed.). Bombay: Goverment Central Press.

Soomro, D. (2007). Karachi, Pleasure Gardens of a Raj City. Lahore: Sang-e-Meel Publications.

Thairani, K. (1973, reprint 1981). British Political issions to Sind (1st ed.). Karachi: Indus Publications.

Yasmeen Lari, M. S. (1996). The Dual City Karachi During the Raj (1st ed.). Karachi: Oxford University Press.

\section{ENDNOTES}

i As the indigenous built forms are more haphazardly places, British laid grid iron planning for first camp base near Saddar Bazaar, later the grid iron also followed in other quarters of Karachi.

ii Communities started to settle down after British, soon after the Crown, philanthropists took participation for raising utilitarian buildings after observing necessary need of the people.

iii The different names can be attributed to the inability of the European tongue to correctly pronounce local languages.

iv After British annexed in Karachi, they declared Bombay and Karachi as international ports, for the exchange of goods and people, a ship Dwarka was started commissioned from the port of Gwadar on the western Makran coast which then sailed between Karachi and Bombay. Other ships such as Sarasvati and Sabarmati were also used. After partition in 1947, the activity was snapped and ends all the links.

$v \quad$ The black town in the northwest, accommodate the burgeoning Indian mercantile population which consists of Old Town, Napier, Bunder and Market quarter and serai quarter served the needs of the Black Town whereas the White Town consists of cantonment, Staff lines and Saddar Bazaar which was used by the White population. The architectural grandeur was seen in the white town such as Sind Club, Frere Hall, Governor House and Collector's Kutchery.

vi Jamatkhanas are prayer areas for Bohris and Agha Khanis (Khojas), and is considered the most sacred and secured place

vii Mr Jalpowala is a Parsi trader, who came from Bombay to Karachi to attend procession in Parsi Dar-e- Meher, told the life in Karachi during British times. He has many friends of different castes and sects and never feels insecure.

viii Mr Jalpowala came Karachi to attend his religious processions at Dar-e-Meher fire temple 